\title{
Investigation of Metal(II)-Curcumin-Glycine Complexes: Preparation, Structural Characterization and Biological Activities
}

\author{
M. VIMALA JOICE ${ }^{1}$ and P. METILDA ${ }^{2 *}$ \\ 'Department of Chemistry and Research, Nesamony Memorial Christian College, Marthandam, \\ Affiliated to Manonmaniam Sundaranar University, Tirunelveli-629165, Tamil Nadu, India. \\ ${ }^{2}$ Department of Chemistry and Research, Nesamony Memorial Christian College, \\ Marthandam-629165, Tamil Nadu, India \\ *Corresponding author E-mail: paul.metilda@gmail.com \\ http://dx.doi.org/10.13005/ojc/370219
}

(Received: February 15, 2021; Accepted: March 16, 2021)

\begin{abstract}
A novel Schiff base obtained from curcumin and glycine was prepared and it was reacted with $\mathrm{Co}, \mathrm{Ni}, \mathrm{Cu}$ and $\mathrm{Zn}$ metals in order to form the stable metal complexes and characterized by elemental analysis, magnetic, molar conductance, IR, UV-Vis., ${ }^{1} \mathrm{H}$ NMR and PXRD. The data shows that the complexes have the structure $\left[\mathrm{M}(\mathrm{II})-(\right.$ cur-gly $\left.) \mathrm{H}_{2} \mathrm{O}\right]$ system. Electronic and magnetic data suggest a tetrahedral geometry for $\mathrm{Co}, \mathrm{Ni}$ and $\mathrm{Zn}$ except $\mathrm{Cu}$ complex has a square planar geometry. The antimicrobial activity of cur-gly and its metal chelates were confirmed against the bacterial species as E. coli, P. aeruginosa, Enterococcus, B. cereus and S. aureus species. Antifungal activity was screened against $C$. albicans, $C$. parapsilosis and $A$. flavus. Metal chelates indicate excellent antimicrobial activity than their parent cur-gly and DNA photo cleavage activity shows that metal chelate effectively cleave the pUC 18 DNA.
\end{abstract}

Keywords: Curcumin, Schiff base, UV-Vis, Glycine, Antimicrobial activity, DNA cleavage.

\section{INTRODUCTION}

Since the cumulative recognition role of metal complexes in biological systems are widely studied in Schiff bases. The ligands are able to coordinate with metals through imine nitrogen and to the aldehyde or ketone. ${ }^{1} 1,7$-bis(4-hydroxy 3-methoxyphenyl)-1,6-hepta-diene-3,5-dione has a specific conjugated $\beta$-diketone moiety and act as an influential natural chelating agent as an strong antioxidant ${ }^{2}$ than Vitamin E. Over the past years complexation with metals has fascinated much consideration necessities for the treatment of Alzheimer's diseases. ${ }^{3,4}$ Curcumin compounds have good combination with other anticancer therapies have been described to prevent the clonogenicity of cancer cells and induce anti-proliferative, apoptotic effects on drug- resistant and sphere-forming cancer cells expressing stem cell-like signs as well as converse the chemoresistance. Amino acids cur-gly

This is an Open Access article licensed under a Creative Commons license: Attribution 4.0 International (CC- BY). Published by Oriental Scientific Publishing Company @ 2018 
form stable compounds and also inhibits the growth of bacterial and fungal strains after complexation. ${ }^{5,6}$ Present investigation ${ }^{7}$ deals with the preparation of the ligand resulting from curcumin-glycine (curgly) and containing $\mathrm{Co}(\mathrm{II}), \mathrm{Ni}(\mathrm{II}), \mathrm{Cu}(\mathrm{II})$ and $\mathrm{Zn}(\mathrm{II})$ complexes and their structural characterization was carried by using various instrumental techniques. The antimicrobial activities and DNA cleavage of cur-gly and its metal(II) complexes have been investigated systematically.

\section{MATERIALS AND METHODS}

\section{Materials}

The AR grade reagents, chemicals including curcumin, glycine, EtOH, methanol, Co/ $\mathrm{Ni} / \mathrm{Cu} / \mathrm{Zn}$ (II) chloride salts were used. All chemicals and solvents were acquired from Merck. Infrared spectrum was recorded on SHIMADZU FT-IR Affinity-1 spectrophotometer by potassium bromide pellet disc method. UV-Vis. studies were carried out on SHIMADZU1800 spectrophotometer between 200-1100 $\mathrm{nm}$ by using suitable solvent. ${ }^{1} \mathrm{H}-\mathrm{NMR}$ of $\mathrm{Zn}$ (II)-cur-gly complexes and cur-gly were recorded Bruker Drx-300 MHz NMR spectrometer using DMSO- $d_{6}$ solvent and Tetramethyl silane as internal standard. Magway MSB Mk 1 Magnetic susceptibility balance was used to carry out the magnetic moment measurements at room temperature.

\section{Preparation of cur-gly}

An ethanolic solution of curcumin $(0.368 \mathrm{~g}$, $0.001 \mathrm{~mol})$, glycine $(0.075 \mathrm{~g}, 0.001 \mathrm{~mol})$ was added dropwise followed by 3 drops of glacial acetic acid and heated under reflux about 3-5 h on a hot plate at $55-60^{\circ} \mathrm{C}$. The resulting solution was reduced to one-third. Dark yellow precipitate was formed, filtered off washed with ethanol and finally dried over fused $\mathrm{CaCl}_{2}{ }^{8,9}$ The preparation route of cur-gly is outlined in Scheme 1.

\section{Preparation of metal complexes [M(II)-(cur-gly) $\mathrm{H}_{2} \mathrm{O}$ ]}

An ethanolic solution of $\mathrm{CoCl}_{2} \cdot 6 \mathrm{H}_{2} \mathrm{O}$, $\mathrm{NiCl}_{2} \cdot 6 \mathrm{H}_{2} \mathrm{O}, \mathrm{CuCl}_{2} \cdot 2 \mathrm{H}_{2} \mathrm{O}$ and $\mathrm{ZnCl}_{2} \cdot \mathrm{H}_{2} \mathrm{O}(1 \mathrm{mmol})$ with an aqueous EtOH solution (15 mL) of cur-gly (1 mmol) was refluxed for about 5 hour. Then the reaction mixture was concentrated to $10 \mathrm{~mL}$ on a boiling water bath and then cooled at room temperature ${ }^{10}$. The solid product formed was filtered, washed with $\mathrm{EtOH}$ and recrystallized from methanol. The proposed reaction pathway is shown in Scheme 2.

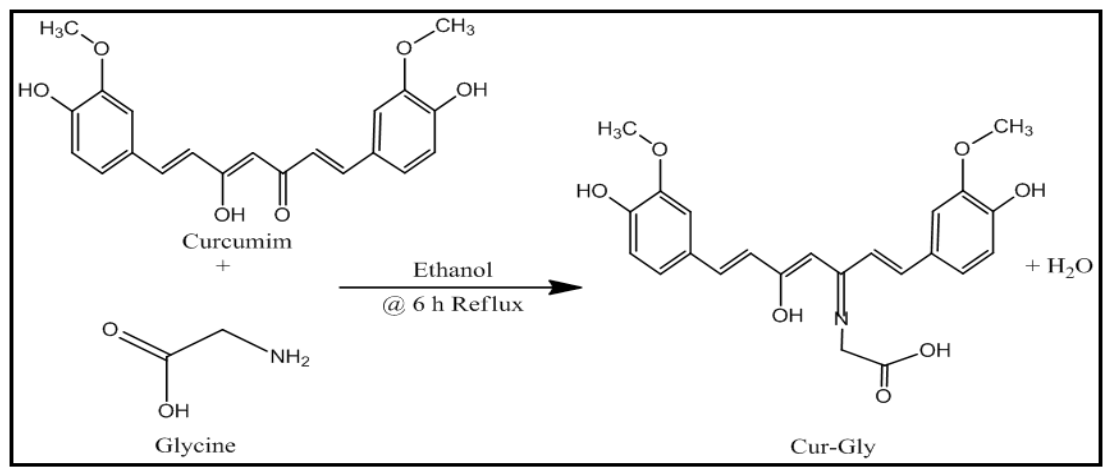

Scheme 1. Synthetic route of cur-gly<smiles>COc1cc(/C=C/C(O)=C/C(/C=C/c2ccc(O)c(OC)c2)=N/CC(=O)O)ccc1O</smiles>

Cur-Gly

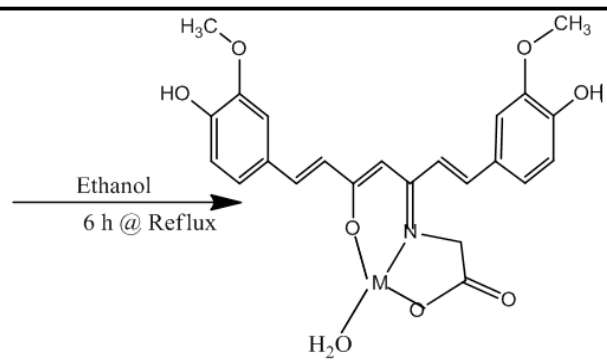

Cur- Gly metal Complexes $\mathrm{M}(\mathrm{II})=\mathrm{Co}, \mathrm{Ni}, \mathrm{Cu}$ or $\mathrm{Zn}$ 


\section{Antimicrobial studies}

The In vitro antimicrobial activity of curgly and [M(II)-(cur-gly) $\left.\mathrm{H}_{2} \mathrm{O}\right]$ in DMSO were studied against the bacterial species such as $P$. aeruginosa, E. coli, Enterococcus, B. cereus and $S$. aureus and fungal species like $C$. albicans, C. parapsilosis and $A$. flavus by Kirby-Bauer disk diffusion ${ }^{11,12}$ technique.

Kirby-Bauer method was used to shade the antimicrobial (bacterial \& fungal) activity. Plates were incubated for 16 to $18 \mathrm{~h}$ at $35-37^{\circ} \mathrm{C}$ aerobically for fastidious organisms. The zones of diameters were reserved to the nearest $\mathrm{mm}$ with vernier calipers or a thin insincere $\mathrm{mm}$ scale values. The point of abrupt diminution of evolution, which in most circumstances resembles with the idea of complete embarrassment growth, was takes as the zone control.

\section{DNA cleavage studies}

Plasmid University of California, DNA models for the cur-gly and [M(II)-(cur-gly) $\mathrm{H}_{2} \mathrm{O}$ ] were evaluated by agar gel-electrophoresis technique based on procedure described in the literature. Test trials $(100 \mathrm{mg} / \mathrm{mL})$ were ready with DMSO solvent; about $5 \mu \mathrm{L}$ of the plasmid was subjected to the test solution and incubated on behalf of $1.5 \mathrm{~h}, 37^{\circ} \mathrm{C}$.
About $10 \mu \mathrm{L}$ of sample/ plasmid (Bromophenol blue dye, 5: 1 molar ratio) was overloaded sensibly into the electrophoresis compartment wells alongside with a standard DNA indication following the Trisacetate buffer $(4.84 \mathrm{~g}$, Trisbase, $\mathrm{pH} 8 ; 0.5 \mathrm{M}$, $\left.\left[\mathrm{CH}_{2} \mathrm{~N}\left(\mathrm{CH}_{2} \mathrm{CO}_{2} \mathrm{H}\right)_{2}\right]_{2} / 1 \mathrm{~L}\right)$. Finally encumbered onto the agar gel ( $1 \%$ gel, $10 \mu \mathrm{g} / \mathrm{mL}$, ethidium bromide). Gel covering the compound samples were linked to power supply of $100 \mathrm{~V}$ for about forty five min., PUC18-DNA possess in the UV-trans-illuminator existed experimental to govern the extent of DNA cleavage analysis. ${ }^{13}$

\section{RESULTS AND DISCUSSION}

\section{Characterization of cur-gly and its [M(II)-(cur-gly) $\mathrm{H}_{2} \mathrm{O}$ ] complexes}

The $\left[\mathrm{M}(\mathrm{II})\right.$-(cur-gly) $\left.\mathrm{H}_{2} \mathrm{O}\right]$ complexes, where $\mathrm{M}(\mathrm{II})=\mathrm{Co} / \mathrm{Ni} / \mathrm{Cu} / \mathrm{Zn}$ are stable at room temperature and soluble in some selected suitable organic solvents such as $\mathrm{EtOH}, \mathrm{CH}_{3} \mathrm{CN}, \mathrm{DMSO}, \mathrm{CHCl}_{3}$ and DMF. The cur-gly and [M(II)-(cur-gly) $\left.\mathrm{H}_{2} \mathrm{O}\right]$ were accomplished in respectable yield and have the melting point $\sim 200^{\circ} \mathrm{C}$. The physico-chemical statistics of cur-gly and [M(II)-(cur-gly) $\left.\mathrm{H}_{2} \mathrm{O}\right]$ are formulated in Table 1.

Table 1: Physical parameters of cur-gly and [M(II)-(cur-gly) $\left.\mathrm{H}_{2} \mathrm{O}\right]$ complexes

\begin{tabular}{|c|c|c|c|c|c|}
\hline Compounds & \multicolumn{2}{|c|}{ Molecular formula } & Colour & Yield(\%) & Molar conductance $(\Omega$ \\
\hline cur-gly & & $\mathrm{O}_{7} \mathrm{~N}$ & dark yellow & 75 & - \\
\hline [Co(II)-(cur-gly) $\left.\mathrm{H}_{2} \mathrm{O}\right]$ & & ${ }_{8} \mathrm{NCO}$ & brown & 73 & 11 \\
\hline$\left[\mathrm{Ni}(\mathrm{II})-(\right.$ cur-gly $\left.) \mathrm{H}_{2} \mathrm{O}\right]$ & & ${ }_{8} \mathrm{NNi}$ & brown & 80 & 8 \\
\hline$\left[\mathrm{Cu}(\mathrm{II})-(\right.$ cur-gly $\left.) \mathrm{H}_{2} \mathrm{O}\right]$ & & ${ }_{8} \mathrm{NCu}$ & dark brown & 70 & 9 \\
\hline$\left[\mathrm{Zn}(\mathrm{II})-\left(\right.\right.$ cur-gly) $\left.\mathrm{H}_{2} \mathrm{O}\right]$ & & ${ }_{8} \mathrm{NZn}$ & colourless & 72 & 12 \\
\hline \multicolumn{6}{|c|}{ Elemental analysis } \\
\hline \multicolumn{6}{|c|}{$\begin{array}{l}\text { The analytical data of cur-gly and [M(II)- } \\
\text { (cur-gly) } \mathrm{H}_{2} \mathrm{O} \text { ] are tabulated in Table } 2 \text {. The elemental } \\
\text { analysis supports good agreement with the molecular }\end{array}$} \\
\hline \multicolumn{6}{|c|}{ Table 2: Analytical data of cur-gly and [M(II)-(cur-gly) $\left.\mathrm{H}_{2} \mathrm{O}\right]$ complexes } \\
\hline \multirow{2}{*}{\multicolumn{2}{|c|}{ Compounds }} & \multicolumn{4}{|c|}{ Found (Cald.) (\%) } \\
\hline & & C & $\mathrm{H}$ & $\mathrm{N}$ & Metal \\
\hline & & $64.94(64$ & $5.45(5.42)$ & $3.29(3.21)$ & - \\
\hline$[\mathrm{Co}(\mathrm{II})-($ & & $55.21(55$ & $4.63(4.23)$ & $2.80(2.69)$ & $11.78(11.32)$ \\
\hline$[\mathrm{Ni}(\mathrm{II})-(\mathrm{C}$ & & $55.24(55$ & $4.64(4.23)$ & $2.80(2.82)$ & $11.74(11.30)$ \\
\hline$[\mathrm{Cu}(\mathrm{II})-($ & & $54.71(54$ & $4.59(4.27)$ & $2.77(2.74)$ & $12.58(12.00)$ \\
\hline$[\mathrm{Zn}(\mathrm{II})-($ & & $54.52(54$ & $4.57(4.14)$ & $2.76(2.64)$ & $12.90(12.40)$ \\
\hline
\end{tabular}




\section{Molar conductance}

The physical molar conductance data of $0.001 \mathrm{~mol}$ solution of [M(II)-(cur-gly) $\left.\mathrm{H}_{2} \mathrm{O}\right]$ complexes in $\mathrm{EtOH}$ are provided in the Table 1. Low molar conductivity data [M(II)-(cur-gly) $\left.\mathrm{H}_{2} \mathrm{O}\right]$ complexes in the range of 8-12 $\Omega^{-1} \mathrm{~cm}^{2} \mathrm{~mol}^{-1}$ suggests their nonelectrolytic behaviour for the prepared [M(II)-(cur-gly) $\mathrm{H}_{2} \mathrm{O}$ ] complexes. ${ }^{14}$

\section{Infrared spectra}

The IR spectrum provides respected evidence concerning the nature of the useful group coordinated to the metal atom. In cur-gly, the infrared spectrum showed a medium intensity band favoured at $1610 \mathrm{~cm}^{-1}$ may be consigned to $v(\mathrm{C}=\mathrm{N})$ stretching vibration. ${ }^{15}$ In the Mid IR spectrum curgly band is found at $3120 \mathrm{~cm}^{-1}$ is ascribed to $-\mathrm{NH}_{2}$ stretching vibration. The bands appeared at 1589 and $1483 \mathrm{~cm}^{-1}$ of cur-gly corresponds to carboxylate asymmetric $v_{\text {as }}(\mathrm{COO}-)$ and symmetric $v_{\text {sy }}(\mathrm{COO}-)$ stretching frequencies. ${ }^{16,17}$ In complexes, the $v(C=N)$ $\mathrm{cm}^{-1}$ band was shifted to lower wavenumber 1610$1570 \mathrm{~cm}^{-1}$ specifies the coordination of azomethine nitrogen atom with metal ion. In metal complexes the asymmetric $v_{\text {sym }}(\mathrm{COO}-)$ and symmetric $v_{\text {asym }}(\mathrm{COO}-)$ stretching bands shifted to lower wave frequency region designates from 1510 and $1402 \mathrm{~cm}^{-1}$ respectively, which reveals the materialization of a bond between metal and carboxylate $\mathrm{O}$ atom. The IR spectra of all M(II)-(cur-gly) $\mathrm{H}_{2} \mathrm{O}$ complexes containing hydration and or coordination water molecules display bands seen at $3487-3354 \mathrm{~cm}^{-1}$ due to $v(\mathrm{O}-\mathrm{H})$ vibration mode of the $\mathrm{H}_{2} \mathrm{O}$ molecules. Therefore the fourth position would be occupied by water molecule in the metal complexes. IR spectra of the complexes also show new peaks at 474-450 $\mathrm{cm}^{-1}$ and $560-568 \mathrm{~cm}^{-1}$ region due to the formation of M-N, and M-O bond. Some important IR spectral assignments of cur-gly and its $\mathrm{M}(\mathrm{II})-\left(\right.$ cur-gly) $\mathrm{H}_{2} \mathrm{O}$ ] complexes is provided in Table 3.

Table 3: Important selected IR bands of cur-gly and [M(II)-(cur-gly) $\mathrm{H}_{2} \mathrm{O}$ ].

\begin{tabular}{|c|c|c|c|c|c|}
\hline \multirow[b]{2}{*}{ Compounds } & \multirow[b]{2}{*}{$v(\mathrm{C}=\mathrm{N})$} & \multicolumn{3}{|c|}{ IR assignments, wavenumber $\left(\mathrm{cm}^{-1}\right)$} & \multirow[b]{2}{*}{$\operatorname{vas}(\mathrm{COO})$} \\
\hline & & $v(\mathrm{M}-\mathrm{N})$ & $v(\mathrm{M}-\mathrm{O})$ & $v s(\mathrm{COO})$ & \\
\hline cur-gly & 1610 & - & - & 1483 & 1589 \\
\hline$\left[\mathrm{Co}(\mathrm{II})-\left(\right.\right.$ cur-gly) $\left.\mathrm{H}_{2} \mathrm{O}\right]$ & 1570 & 450 & 560 & 1408 & 1523 \\
\hline$\left[\mathrm{Ni}(\mathrm{II})-\left(\right.\right.$ cur-gly) $\left.\mathrm{H}_{2} \mathrm{O}\right]$ & 1573 & 451 & 568 & 1417 & 1513 \\
\hline$\left[\mathrm{Cu}(\mathrm{II})-\left(\right.\right.$ cur-gly) $\left.\mathrm{H}_{2} \mathrm{O}\right]$ & 1587 & 474 & 562 & 1402 & 1510 \\
\hline$\left[\mathrm{Zn}(\mathrm{II})-\left(\right.\right.$ cur-gly) $\left.\mathrm{H}_{2} \mathrm{O}\right]$ & 1590 & 459 & 563 & 1413 & 1519 \\
\hline
\end{tabular}

\section{PNMR spectra}

PNMR spectra of cur-gly and its [Zn(II)(cur-gly) $\mathrm{H}_{2} \mathrm{O}$ ] were studied in DMSO-d ${ }_{6}$ solvent. PNMR spectra of (a) cur-gly and (b) [Zn(II)-(cur-gly) $\mathrm{H}_{2} \mathrm{O}$ ] are given in Fig. 1. PNMR spectra of cur-gly displays a peak at $\delta 12.34 \mathrm{ppm}$ which may be attributable to the enolic - $\mathrm{OH}$ group of curcumin moiety. These PNMR spectral signals vanished in all complexes due to the deprotonation of $\mathrm{OH}$ group. The azomethine proton of the zinc complex

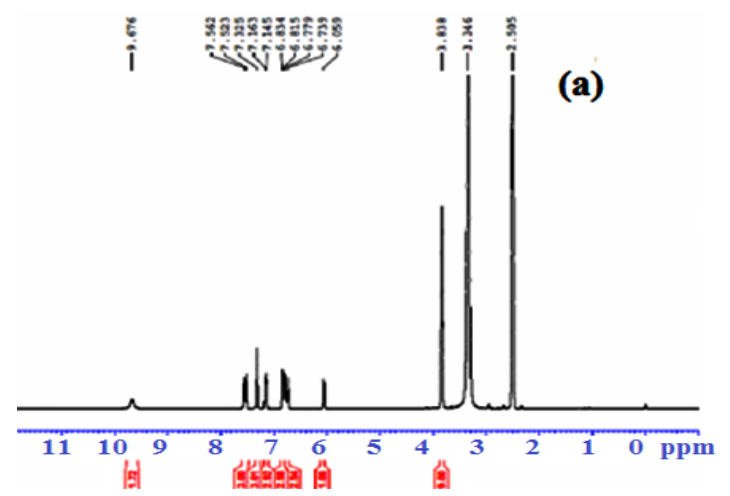

appeared $\delta 9.67$ ppm indicating complexation of nitrogen atom of the azomethine with $\mathrm{Zn}(\mathrm{II})$ ion. The peaks at $\delta 6.05$ ppm in Schiff base and the complex are assignable to two phenolic - $\mathrm{OH}$ group in the curcumin moiety ${ }^{18,19}$ which suggested that they are not involved in the coordination. The multi signals within the range $\delta 6.73-7.56 \mathrm{ppm}$ are assigned to the aromatic protons of ring in metal(II) complexes $\delta$ 3.34-3.83 ppm for asymmetric proton while the $\mathrm{CH}_{2}$ protons are shown in the $\delta 2.50 \mathrm{ppm}$.

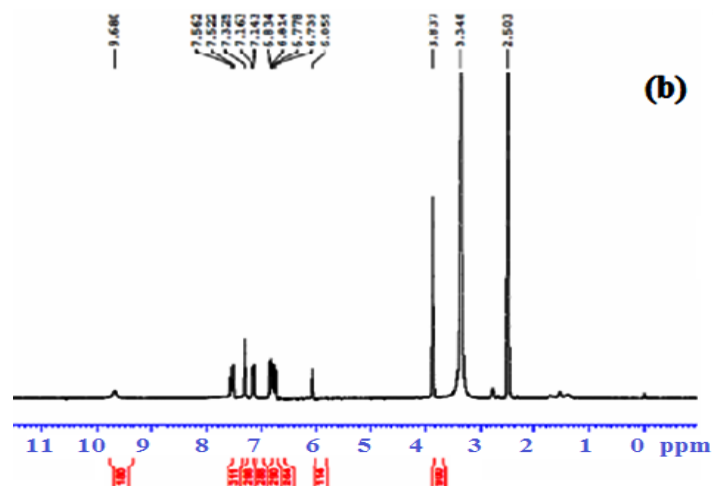

Fig. 1. PNMR spectra of (a) cur-gly and (b) $\left[\mathrm{Zn}(\mathrm{II})-\left(\right.\right.$ cur-gly) $\left.\mathrm{H}_{2} \mathrm{O}\right]$ 


\section{Electronic absorption spectral analysis}

UV-Vis. spectrum of cur-gly exhibited a band centered at $330 \mathrm{~nm}$, which is the characteristic transition of $n \rightarrow \pi^{\star}$ agrees to azomethine moiety. This spectral electronic band may be shifted to higher absorption wavelength region demonstrating the status of coordination. The electronic spectra of [Co(II)-(cur-gly) $\mathrm{H}_{2} \mathrm{O}$ ] and [ $\mathrm{Ni}(\mathrm{II})$-(cur-gly) $\left.\mathrm{H}_{2} \mathrm{O}\right]$ displays an broad absorption spectral band regions ensued at 620 and $615 \mathrm{~nm}$ respectively may be attributed to ${ }^{4} \mathrm{~A}_{2 \mathrm{~g}} \rightarrow{ }^{4} \mathrm{~T}_{1 \mathrm{~g}}$ transition, propose tetrahedral geometrical environment for these complexes. The $\left[\mathrm{Cu}(\mathrm{II})\right.$-(cur-gly) $\left.\mathrm{H}_{2} \mathrm{O}\right]$ demonstrated a broad band concentrated around $670 \mathrm{~nm}$ corresponds to ${ }^{2} \mathrm{~B}_{1 \mathrm{~g}} \rightarrow$ ${ }^{2} \mathrm{~A}_{1 \mathrm{~g}}$ transition proposes square planar geometrical behaviour for this complex. The [ $\mathrm{Zn}(\mathrm{II})-\left(\right.$ cur-gly) $\left.\mathrm{H}_{2} \mathrm{O}\right]$ is diamagnetic and favours four coordinated ${ }^{20,21}$ tetrahedral geometry would be desirable for this complex. Electronic spectral data [M(II)-(cur-gly) $\left.\mathrm{H}_{2} \mathrm{O}\right]$ are listed in Table 4.

Table 4: Electronic data of [M(II)-(cur-gly) $\left.\mathrm{H}_{2} \mathrm{O}\right]$

\begin{tabular}{lccc}
\hline Complexes & $\lambda_{\max }(\mathrm{nm})$ & Transitions & Geometry \\
\hline$\left[\mathrm{Co}(\mathrm{II})\right.$-(cur-gly) $\left.\mathrm{H}_{2} \mathrm{O}\right]$ & 620 & ${ }^{4} \mathrm{~A}_{2 \mathrm{~g}} \rightarrow{ }^{4} \mathrm{~T}_{1 \mathrm{~g}}$ & Tetrahedral \\
{$\left[\mathrm{Ni}(\mathrm{II})\right.$-(cur-gly) $\left.\mathrm{H}_{2} \mathrm{O}\right]$} & 615 & ${ }^{4} \mathrm{~A}_{2 \mathrm{~g}} \rightarrow{ }^{4} \mathrm{~T}_{1 \mathrm{~g}}$ & Tetrahedral \\
{$\left[\mathrm{Cu}(\mathrm{II})\right.$-(cur-gly) $\left.\mathrm{H}_{2} \mathrm{O}\right]$} & 670 & ${ }^{2} \mathrm{~B}_{1 \mathrm{~g}} \rightarrow{ }^{2} \mathrm{~A}_{1 \mathrm{~g}}$ & Square planar \\
{$\left[\mathrm{Zn}(\mathrm{II})\right.$-(cur-gly) $\left.\mathrm{H}_{2} \mathrm{O}\right]$} & 330 & No d-d & Tetrahedral \\
\hline
\end{tabular}

Magnetic moment studies

The observed magnetic susceptibility value

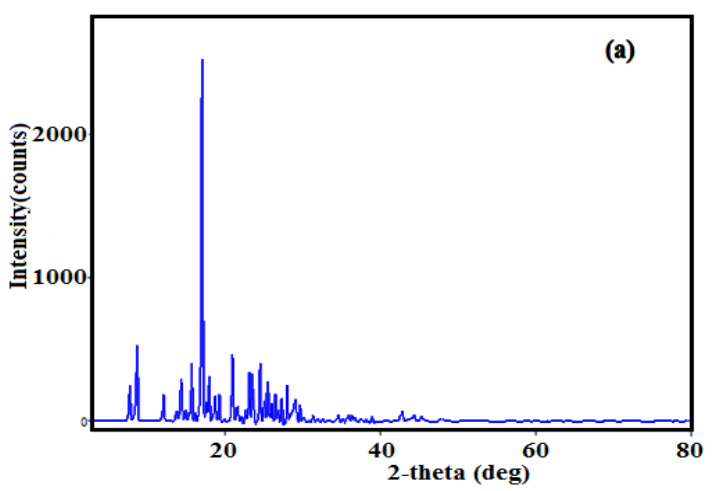

Fig. 2. Powder XRD pattern of (a) cur-gly and (b) [Cu(II)-(cur-gly) $\left.\mathrm{H}_{2} \mathrm{O}\right]$

\section{Biological Studies \\ Antimicrobial activity}

Antibacterial activity of cur-gly and [M(II)(cur-gly) $\mathrm{H}_{2} \mathrm{O}$ ] complexes have been assessed by measuring the zone of growth inhibition against $E$. coli, P. aeruginosa, Enterococcus, B. cereus and $S$. aureus. The antifungal activity was screened against $C$. albicans, $C$. parapsilosis and $A$. flavus. of [Co-(cur-gly) $\mathrm{H}_{2} \mathrm{O}$ ] and [Ni-(cur-gly) $\mathrm{H}_{2} \mathrm{O}$ ] systems are observed at 4.0 and 3.9 B.M. respectively, corresponds to tetrahedral geometry for these complex systems. ${ }^{22}$ Normally square planar [Cu(II)(cur-gly) $\mathrm{H}_{2} \mathrm{O}$ ] exhibit magnetic moments in the range 1.8-2.1 B.M. The observed magnetic moment value of [Cu(II)-(cur-gly) $\mathrm{H}_{2} \mathrm{O}$ ] is 1.9 B.M., which is the characteristic for square planar geometry of the [Cu(II)-(cur-gly) $\mathrm{H}_{2} \mathrm{O}$ ]. Magnetic measurements and visible spectral data provide sufficient support in assigning the geometry of the metal complexes.

\section{Powder XRD}

The PXRD patterns of cur-gly and its [Cu(II)-(cur-gly) $\mathrm{H}_{2} \mathrm{O}$ ] complex are measured in the range $2 \theta=0-80 \AA$, Fig. 2(a, b). By Scherer's equation, $d_{x r d}=0.89 \lambda / \beta \cos \theta$ ), the average grain size dXRD was calculated, 'd' characterizes the average grain size phases under examination. ' $\lambda$ ' indicate the wavelength of $X$-ray beam used. ' $\beta$ ' is the full-width half maxima of diffraction, and ' $\theta$ ' is the Bragg's angle. From the XRD patterns, the average grain size for cur-gly and [Cu(II)-(cur-gly) $\mathrm{H}_{2} \mathrm{O}$ ] are $67 \mathrm{~nm}$ and $50 \mathrm{~nm}$ respectively for the above mentioned compounds. XRD patterns subsequently on complexetion, the particle size decreases, indicate that the metal-ligand coordination.

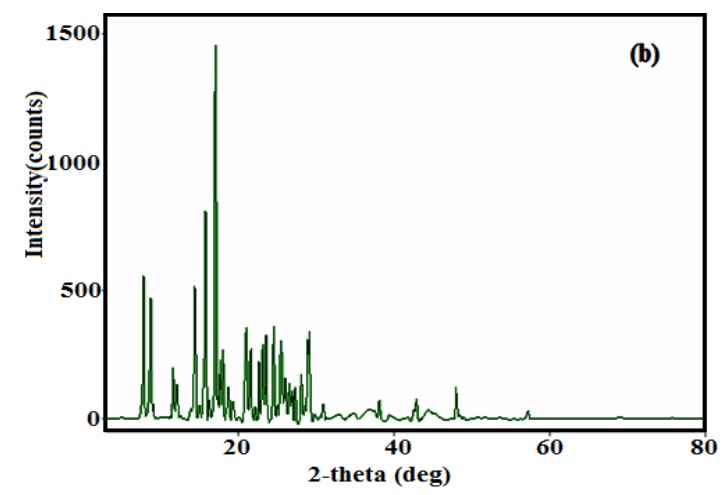

Biological activities of cur-gly and its complexes are summarized in Table 5 and the results infer that $\mathrm{Co}$ and $\mathrm{Cu}$ metal complexes have more inhibition towards $S$. aureus and [Cu(II)-(cur-gly) $\mathrm{H}_{2} \mathrm{O}$ ] has added inhibition towards E. coli. Ni, $\mathrm{Cu}$ and $\mathrm{Zn}$ have more inhibition towards $C$. parapsilosis. Cur-gly and its [M(II)-(cur-gly) $\mathrm{H}_{2} \mathrm{O}$ ] were compared its shows that, the metal chelates are more effectively inhibits 
the microorganism than their parent cur-gly against the same microorganism under indistinguishable experimental conditions. Complexation increases the polarity of metal ion by the partial distribution of its positive charge with donor groups in complexes. This increases the lipophilic environment of the central metal atom which ultimately favours its permeation through the lipid level of the cell membrane. ${ }^{23-26}$

Table 5: Antibacterial activities of cur-gly and its [M(II)-(cur-gly) $\left.\mathrm{H}_{2} \mathrm{O}\right]$

\begin{tabular}{|c|c|c|c|c|c|c|c|}
\hline \multirow[t]{2}{*}{ Microbial species } & \multirow[b]{2}{*}{ cur-gly } & \multicolumn{4}{|c|}{ Zone of inhibition (mm) } & & \multirow[t]{2}{*}{ Standard Amikacin } \\
\hline & & Co & $\mathrm{Ni}$ & $\mathrm{Cu}$ & $\mathrm{Zn}$ & & \\
\hline \multirow[t]{6}{*}{ Bacterial } & $P$. aeruginosa & 8 & 10 & 11 & 9 & 9 & 24 \\
\hline & S. aureus & 9 & 15 & 9 & 16 & 13 & 23 \\
\hline & E. coli & 11 & 13 & 10 & 15 & 10 & 20 \\
\hline & Enterococcus & - & 14 & 9 & 13 & 10 & 18 \\
\hline & B. cereus & - & 12 & 10 & 12 & 11 & 28 \\
\hline & C. albicans & 10 & 11 & - & 11 & - & 18 \\
\hline \multirow[t]{2}{*}{ Fungal } & C. parapsilosis & - & - & 14 & 11 & 12 & 14 \\
\hline & A. flavus & - & - & - & - & - & 8 \\
\hline
\end{tabular}

\section{DNA Cleavage}

The pUC18 (Plasmid University of California) DNA using agarose gel electrophoresis experiment was conducted in the present investigation at $37^{\circ} \mathrm{C}$ using our synthesized cur-gly and its [M(II)-(curgly) $\mathrm{H}_{2} \mathrm{O}$ ] in existence of hydrogen peroxide as an oxidant. It is shown in Fig. 3, some complexes exhibit cleavage activity in presence of hydrogen peroxide at the low concentration levels. In Lane 1 shows the control DNA. Lane 2 does not display any substantial cleavage of pUC18 DNA even on longer exposure time interval. ${ }^{27-31}$ From the figure observed result shows, the metal complexes of [ $\mathrm{Zn}$ (II)-(cur-gly) $\left.\mathrm{H}_{2} \mathrm{O}\right]$ and [Ni(II)-(cur-gly) $\mathrm{H}_{2} \mathrm{O}$ ] effectively cleaved the supercoiled plasmid DNA pUC18.

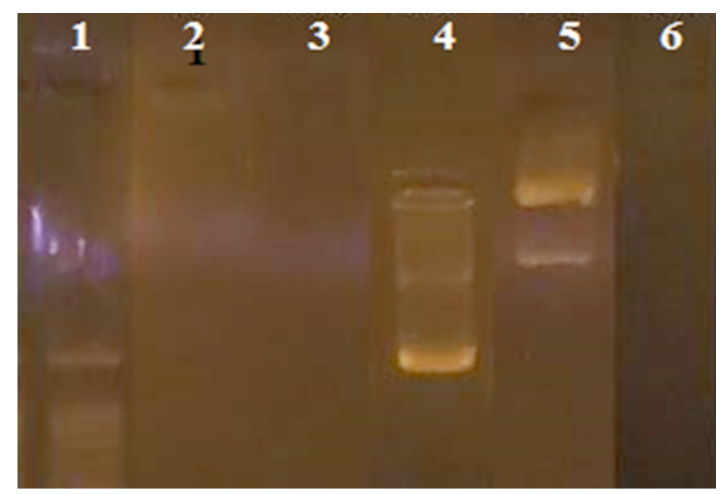

Fig. 3. DNA Cleavage of cur-gly and its [M(II)-(cur-gly) $\left.\mathrm{H}_{2} \mathrm{O}\right]$

\section{Lane 1 Marker DNA control}

Lane 2 Plasmid DNA + cur-gly

Lane 3 Plasmid DNA + [Co(II)-(cur-gly) $\left.\mathrm{H}_{2} \mathrm{O}\right]$

Lane 4 Plasmid DNA + [Zn(II)-(cur-gly) $\left.\mathrm{H}_{2} \mathrm{O}\right]$
Lane 5 Plasmid DNA + [Cu(II)-(cur-gly) $\left.\mathrm{H}_{2} \mathrm{O}\right]$

Lane 6 Plasmid DNA + [Ni(II)-(cur-gly) $\left.\mathrm{H}_{2} \mathrm{O}\right]$

\section{CONCLUSION}

Metal(II) complexes of imine-linked curgly has been synthesized and characterized. The experimental and theoretical results shows that the cur-gly is complexed to metal ions via azomethine $\mathrm{N}$ atom, carboxylate $\mathrm{O}$ atom. Geometrical structures are found to be tetrahedral for [Co(II)-(cur-gly) $\left.\mathrm{H}_{2} \mathrm{O}\right]$, [Ni(II)-(cur-gly) $\left.\mathrm{H}_{2} \mathrm{O}\right]$ and [ $\mathrm{Zn}(\mathrm{II})$-(cur-gly) $\mathrm{H}_{2} \mathrm{O}$ ], square planar for [Cu(II)-(cur-gly) $\left.\mathrm{H}_{2} \mathrm{O}\right]$. The crystalline nature and crystallite size have been obtained from PXRD analysis. The antimicrobial activity and DNA cleavage study revealed that all $\left[\mathrm{M}(\mathrm{II})-\left(\right.\right.$ cur-gly) $\left.\mathrm{H}_{2} \mathrm{O}\right]$ exhibit good activities as compared to cur-gly.

\section{ACKNOWLEDGEMENT}

Authors are thankful for using the instrumental facilities of IR, UV-Vis and PXRD provided in JA College Periyakulam. NMR in GRI Gandhi gram and magnetic studies in DRDO Laboratory, Thiagarajar College, Madurai, Tamil Nadu. We are thankful to Medauxin, Bangalore and Scubber Diagnstic Centre, Nagercoil, Tamil Nadu for the biological studies.

\section{Conflicts of Interest}

The authors declare no conflict of interest.

\section{REFERENCES}

1. Akhter S.; Zaman H.U.; Mir S.; Dar A;M.; Shrivastava S.; Synthesis of Schiff base metal complexes: a concise review. Eur. Chem. Bull., 2017, 6(10), 475-83. 
2. Zhang Y.; Khan A.R.; Fu M.; Zhai Y.; Yu A.; Zhai G.; The progresses in curcuminoids-based metal complexes: especially in cancer therapy. Future Med. Chem., 2019, 11(09), 1035-56.

3. Wanninger S.; Lorenz V.; Subhan A.; Edelmann F.T.; Metal complexes of curcumin - synthetic strategies, structures and medicinal applications. Chem. Soc. Rev., 2015, 44(15), 4986-5002.

4. Shakeri A.; Panahi Y.; Johnston T.P.; Sahebkar A.; Biological properties of metal complexes of curcumin. Bio. Factors, 2019, 45(3), 304-17.

5. Pervaiz M.; Ahmad I.; Yousaf M.; Kirn S.; Munawar A.; Saeed Z.; Synthesis, spectral and antimicrobial studies of amino acid derivative Schiff base metal (Co, $\mathrm{Mn}, \mathrm{Cu}$, and Cd) complexes. Spectrochim. Acta A., 2019, 206, 642-9.

6. Joly A.; LathaM.S.; Synthesis of nanocurcuminalginate conjugate and its characterization by XRD, IR, UV-Vis and Raman spectroscopy. Orient.J. Chem., 2019, 35(2), 751-756.

7. Saritha T.J.; Metilda P.; Synthesis, Spectroscopic characterization and Larvicidal activity of some Transition Metal Complexes of Schiff base derived from Curcumin and 2-aminophenol, IJETA., 2018, 5(5), 1-5.

8. Sevgi F.; Bagkesici U.; Kursunlu A.N.; Guler E.; $\mathrm{Fe}(\mathrm{III}), \mathrm{Co}$ II), $\mathrm{Ni}(\mathrm{II}), \mathrm{Cu}(\mathrm{II})$ and $\mathrm{Zn}$ (II) complexes of Schiff bases based-on glycine and phenylalanine: Synthesis, magnetic/ thermal properties and antimicrobial activity. J. Mol. Struct., 2018, 1154, 256-60.

9. Thiravidamani C.; Tarannum N.; Evaluation of DNA intercalation study and biological profile of a series of Schiff base metal(II) complexes derived from amino acid. Inorg. Nano-Met. Chem., 2020, 1-2.

10. Sebastian M.; Arun V.; Robinson P.P.; Leeju P.; Varsha G.; Varghese D.; Template synthesis and spectral characterization of some Schiff base complexes derived from quinoxaline2-carboxaldehyde and L-histidine. J. Coord. Chem., 2011, 64(3), 525-33.

11. Jones R.N.; Ballow C.H.; Biedenbach D.J.; Hospital E.C.; Hospital S.M.; Hospital F.C.; Hospital G.M.; Pettis Memorial V.A.; Center L.L.; Center U.M.; Multi-laboratory assessment of the linezolid spectrum of activity using the Kirby-Bauer disk diffusion method: Report of the Zyvox@ Antimicrobial Potency Study (ZAPS) in the United States. Diagn. Micr. Infec. Dis., 2001, 4O(1-2), 59-66.
12. Yang X.; Wang D.; Zhou Q.; Nie F.; Du H.; Pang X.; Fan Y.; Bai T.; Xu Y.; Antimicrobial susceptibility testing of enterobacteriaceae: determination of disk content and Kirby-Bauer breakpoint for ceftazidime/avibactam. BMC Microbiol., 2019, 19(1), 1-7.

13. Zehra S.; Roisnel T.; Arjmand F.; Enantiomeric amino acid Schiff base $\mathrm{Cu}$ (II) complexes as a new class of RNA-targeted metallointercalators: Single $X$-ray crystal structural details, comparative In vitro DNA/RNA binding profile, cleavage and cytotoxicity. ACS Omega., 2019, 4(4), 7691-705.

14. Mariyappan M.V.; Synthesis and characterization of some transition metal complexes of Schiff base derived from 2,4dihydroxybenzaldehyde. Iranian J. Pharm. Sci., 2019, 15(3), 29-40.

15. Jenisha, Theodore D.S.; Priyadharsini J.; Schiff Base ligand its complexes and their FT-IR spectroscopy studies. Inter. J. Appl. Bio-Eng., 2015, 9(1), 1-4.

16. Abu-Dief A.M.; Nassr L.A.; Tailoring, physicochemical characterization, antibacterial and DNA binding mode studies of $\mathrm{Cu}$ (II) Schiff bases amino acid bioactive agents incorporating 5-bromo-2-hydroxybenzaldehyde. J. Iranian Chem. Soc., 2015, 12(6), 943-55.

17. Abdel-Rahman LH.; El-Khatib R.M.;Nassr L.A.; Abu-Dief A.M.; Lashin F.E.; Design, characterization, teratogenicity testing, antibacterial, antifungal and DNA interaction of few high spin $\mathrm{Fe}$ (II) Schiff base amino acid complexes. Spectrochim. Acta A., 2013, 111, 266-76.

18. Vhanale B.T.; Deshmukh N.J; Shinde A.T.; Synthesis, characterization, spectroscopic studies and biological evaluation of Schiff bases derived from 1-hydroxy-2-acetonapthanone. Heliyon., 2019, 5(11), 02774.

19. Kareem A.; Khan M.S.; Nami S.A.; Bhat S.A.; Mirza A.U.; Nishat N.; Curcumin derived Schiff base ligand and their transition metal complexes: Synthesis, spectral characterization, catalytic potential and biological activity. J. Mol. Struct., 2018, 1167, 261-73.

20. Prasannan D.; Ravikanth M.; Synthesis, properties and coordination chemistry of [14] triphyrins (2.1. 1). Coord. Chem. Rev., 2020, 407, 213172. 
21. Al Zoubi W.; AlHamdani A.A.; Ahmed S.D.; Ko Y.G.; Synthesis, characterization, and biological activity of Schiff bases metal complexes. J. Phy. Org. Chem., 2018, 31(2), 3752.

22. Neelakantan M.A.; Balamurugan K.; Balakrishnan C.; Subha L.; Interaction of amino acid Schiff base metal complexes with DNA/BSA protein and antibacterial activity: spectral studies, DFT calculations and molecular docking simulations. Appl. Organomet. Chem., 2018, 32(4), e4259.

23. Janaki G.B.; Raj X.J.; Antioxidant and catalytic activity of effective curcumin based copper complexes of 2-aminobenzothiazole derivatives. Inter. J. Appl. Eng. Res., 2018, 13(10), 8081-9.

24. Hameed A.; Al-Rashida M.; Uroos M.; Abid A.S.; Khan K;M.; Schiff bases in medicinal chemistry: A patent review (2010-2015). Expert opinion on therapeutic Patents., 2017, 27(1), 63-79.

25. Raman N.; Sakthivel A.; Pravin N.; Exploring DNA binding and nucleolytic activity of few 4-aminoantipyrine based amino acid Schiff base complexes: A comparative approach. Spectrochim. Acta., A, 2014, 125, 404-13.

26. Omidi S.; Kakanejadifard A.; A review on biological activities of Schiff base, hydrazone, and oxime derivatives of curcumin. RSC Adv., 2020, 10(50), 30186-202.

27. Pröhl M.; Schubert U.S.; Weigand W.; Gottschaldt M.; Metal complexes of curcumin and curcumin derivatives for molecular imaging and anticancer therapy. Coord. Chem. Rev., 2016, 30, 32-41.

28. Chandrasekar T.; Raman N.; Exploration of cellular DNA lesion, DNA-binding and biocidal ordeal of novel curcumin based Knoevenagel Schiff base complexes incorporating tryptophan: Synthesis and structural validation. J. Mol. Struct., 2016, 1116, 146-54.

29. Rodrigues F.C.; Kumar N.A.; Thakur G.; Developments in the anticancer activity of structurally modified curcumin: An up-to-date review. Eur. J. Med. Chem., 2019, 177, 76-104.

30. Selwin Joseyphus R.; Sivakumaran Nair M.; Synthesis, characterization and antimicrobial activity of transition metal complexes with the Schiff base derived from imidazole-2carboxaldehyde and glycylglycine. J. Coord. Chem., 2009, 62(2), 319-327.

31. Selwin Joseyphus R.; Dhanaraj C.J.; Nair M.S.; Synthesis and characterization of some Schiff base transition metal complexes derived from vanillin and $L(+)$ alanine. Transition Met. Chem., 2006, 31(6), 699-702. 